\title{
Pandemi Sonrası Dönemde Kişi Başına Düşen Kentsel Yeşil Alan İhtiyacını Yeniden Düşünmek
}

\author{
Sinem Özdede ${ }^{1}$ \\ ORCID: 0000-0002-6887-085X
}

\author{
Dalya Hazar Kalonya ${ }^{2}$
}

ORCID: 0000-0003-0075-0234

\author{
Aysun Aygün ${ }^{3}$ \\ ORCID: 0000-0002-9403-7124
}

\section{Öz}

COVID-19 pandemisi kentsel açık ve yeşil alanların önemini yeniden tartışmaya açmıştır. Karbon emisyonunu azaltmak için önerilen kompakt yapılaşma politikalarının, pandemi sonrası dönemin sosyal mesafe ihtiyacı ile çelişerek yoğunluk konusunda bir ikileme yol açtığı görülmektedir. Pandemi sürecinde ortaya çıkan sosyal izolasyon ihtiyacı ve kentsel açık yeşil alanların azlı̆̆ı, kentlileri evlerinde hapsolmaya itmiştir. Buna karşın daha fazla açık yeşil alana sahip kentler, insanların birbiriyle daha az etkileştiği alanlar yaratarak kentlilere hareket imkânı să̆lamıştır. Bu bağlamda pandemi sonrası dönemde kentsel yeşil alan standartlarının yeniden düşünmek daha să̆lıklı kentler tasarlanması için bir ihtiyaçtır. Yapılan çalışma, kentlerde ihtiyaç duyulan açık ve yeşil alan miktarlarını hesaplamaya yönelik hipotetik bir model üzerinden pandemi sonrası dönemde kişi başına düşen kentsel yeşil alan ihtiyacını incelemektedir. "Pandemi Sonrası Yeşil Alanlar" (PS-YA) olarak isimlendirilen model; kişisel sosyal mesafe, gruplar arası istenen mesafe ve yeşil alan kullanım sıklığı dikkate alınarak matematiksel olarak formüle edilmiştir. Yapılan çalışma kapsamında, pandemi sonrası dönemde kişi başına düşen optimum kentsel yeşil alan ihtiyacının belirlenmesi için ileride yapılacak araştırmalara bilimsel altlık oluşturması ve kentsel yeşil alan standartlarının iyileştirilmesi amaçlanmıştır.

Anahtar Kelimeler: Kent planlama, kentsel yeşil alan, să̆lıklı kent, pandemi, COVID-19.

\footnotetext{
${ }^{1}$ Dr. Öğr. Üyesi, Pamukkale Üniversitesi, E-mail: sinemozdede@gmail.com

${ }^{2}$ Dr. Öğr. Üyesi, Pamukkale Üniversitesi, E-mail: dalyahazar@gmail.com

${ }^{3}$ Araş. Gör. Dr., Pamukkale Üniversitesi, E-mail: aygunaysun@gmail.com

idealkent @ Kent Araştırmaları Dergisi (Journal of Urban Studies)

http://idealkentdergisi.com

Geliş Tarihi Received Date: 19.12.2020 Kabul Tarihi Accepted Date: 25.08.2021
} 


\title{
Rethinking the Need for Urban Green Space Per Capita in the Post-Pandemic Era
}

\author{
Sinem Özdede ${ }^{1}$ \\ ORCID: 0000-0002-6887-085X
}

Dalya Hazar Kalonya ${ }^{2}$

ORCID: 0000-0003-0075-0234

\author{
Aysun Aygün ${ }^{3}$ \\ ORCID: 0000-0002-9403-7124
}

\begin{abstract}
COVID-19 pandemic has re-brought forward the importance of urban open spaces. It is seen that the compact housing policies proposed to reduce carbon emissions conflict with the need for social distance in the post-pandemic era in terms of density. The need for social isolation emerged during the pandemic and the scarcity of urban open green spaces have been effective in keeping the citizens in their homes. However, cities with more open green spaces have provided the mobility of citizens since people interact less with each other. In this context, rethinking urban green space standards in the post-pandemic era is a necessity for designing healthier cities. The study examines the need for urban green space per capita in the post-pandemic era through a hypothetical model to calculate the amount of open and green space needed in cities. The model named "Post-Pandemic Green Areas" (PS-YA) has been mathematically formulated taking into personal social distance, desired distance between-groups and frequency of the use of green space. The study aims to establish a scientific basis for future research to determine the optimum need for urban green space per capita in the post-pandemic era and to improve urban green space standards.
\end{abstract}

Keywords: Urban planning, urban green space, healthy city, pandemic, COVID-19.

\footnotetext{
${ }^{1}$ Assist. Prof. Dr., Pamukkale University, E-mail: sinemozdede@gmail.com

2 Assist. Prof. Dr., Pamukkale University, E-mail: dalyahazar@gmail.com

${ }^{3}$ Res. Assist. Dr., Pamukkale, University, E-mail: aygunaysun@gmail.com

idealkent @ Kent Araştırmaları Dergisi (Journal of Urban Studies) 


\section{Giriş}

COVID-19 pandemisi hayatın her alanında olduğu gibi, kentsel alanda da sosyal mesafe ihtiyacı sebebiyle günlük yaşam pratiklerini derinlemesine etkilemiştir. Bu dönemde özellikle kentsel açık alanların ve sokakların önemi; sokak cephelerinin, meydanların, sokaklarla bağlantılı kentsel açık alanlarda ve parklarda gerçekleşen gündelik faaliyetlerin çeşitliliği, yeterliliği ve niteliği yeniden tartışılmaya başlanmıştır. Son yıllarda karbon emisyonunun azaltılması, toplu taşım kullanımının arttırılması ve işe gidiş geliş sürelerini kısaltılması için önerilen kompakt planlama ve yoğunlaştırma politikaları, pandemi ve pandemi sonrası dönemde ortaya çıkan sosyal mesafe ihtiyacı ile çelişerek yoğunluk ikilemine yol açmıştır.

Pandemi sürecinde küçük apartman dairelerine ve gittikçe kapalı hale gelen "yeni kamusal mekanlara” sıkışan kentliler, açık alanlara erişmekte güçlük çekmişlerdir. Bu dönemde, insanların toplu taşım araçlarından kaçındığını ve bireysel ulaşım yollarını tercih ettikleri görülmüştür. Özel araç kullanamayan kullanıcılar ise, yürüyüş ve bisiklet alternatiflerine yönelmişlerdir. Bu durum kentlerde erişilebilir açı alanlara, yeşil koridorlara ve bisiklet yollarına ihtiyacı bir kez daha ortaya koymuştur. Bu ihtiyaç ise şehir plancları ve peyzaj mimarlarını nasıl daha sürdürülebilir ve sağlıklı kentler yaratılabileceğine ilişkin araştırma yapmaya yöneltmektedir (Barbarossa, 2020).

Dünyanın çeşitli ülkelerinde, pandemi sonrası dönemde halk sağlığını iyileştirmek, karbon salınımını azaltmak, kentsel eşitsizliği azaltmak ve kamusal alanda sürdürülebilir ekonomik iyileşmeyi hızlandırmak için pratik ölçütlerden oluşan ortak bir çerçeve belirlemeye çalışılmaktadır. Bu sebepten, kent kullanıcılarının sosyal mesafeyi gözeterek güvenle hareket edebileceği, bisikletli ve yaya ulaşımının artırılacağı güzergâhların ve mahalle ölçeğinde güvenli ve erişilebilir kamusal yeşil alan tasarımlarının yakın gelecekte standartlaşacă̆ öngörülmektedir (Barbarossa, 2020). Bu bağlamda, pandemi sonrası dönemde gerekli stratejileri belirlemek ve sağlıklı kentler tasarlayabilmek için, peyzaj mimarları, şehir plancılar, mimarlar vb. meslek gruplarına önemli sorumluluklar düşmektedir.

Kentlerde açık ve yeşil alanların erişilebilir olduğu alanlarda, bireylerin ev yerine dışarıda olma eğilimleri olduğu gözlemlenmiştir. Ancak, büyük şehirlerin var olan açık alan kapasitelerinin sosyal mesafe kapsamında, taşıma kapasitesinin oldukça üzerinde olduğu bir gerçektir. Kentlilerin küçük apartman dairelerinde ve kapalı "kamusal" mekanlarda izole olmasının, metropollerden 
kent çeperlerine ve kırsal alanlara kitlesel göçleri tetikleyebileceği de tartışılmaktadir (Maxwell, 2020).

Kentsel açık alanlar ve özellikle kent parkları, yaşanabilir ve sağlıklı kentlerin merkezinde konumlanmaktadır. Yoğunluğun bir tehdit olduğu pandemi sonrası dönemde, sağlıklı bir toplumsal hayatın yeniden tesisi için açık alanların, kapalı mekânların bir uzantısı ve aktif yaşam alanları olarak yeniden tasarlanması gerekmektedir. Sosyal mesafe ve açık hava ihtiyacı; kentsel mekânları gündelik hayat için işlevsel hale getirmek üzere özgün çözüm önerilerine mecbur bırakırken, kent içerisinde yer alan parklar da yeniden değerlendirilmeye ihtiyaç duymaktadır.

3194 sayılı İmar Kanunu'nun Mekânsal Planlar Yapım Yönetmeliğinde Türkiye'de kişi başına düşen yeşil alan standard $\mathbf{1 0} \mathbf{~ m}^{\mathbf{2}}$ olarak belirlenmiştir. Ancak, pandemi sonrası dönemin yeni normal standartlarının getirdiği sosyal mesafe zorunluluğu, kişi başına düşen sosyal alan büyüklüklerini de etkilemektedir. Bu bağlamda yapılan çalışma, COVID-19 pandemisi ve diğer faktörlere bağlı riskleri minimuma indirmek; kentsel hareketliliği ve erişilebilirliği, bisiklet ve yürüyüş gibi bireysel "yeşil" ulaşım türlerini odağına alarak artırmak; sağlıklı, adil ve sürdürülebilir kentler tasarlayarak toplum sağlığını yeniden tesis etmek için yeni normal standartlara göre kişi başına düşen yeşil alan miktarın hesaplayan hipotetik bir model önermektedir.

\section{Pandemi Sonrası Dönemde Kentsel Alanlar}

Pandemi kelimesinin kökeni Yunanca pandemos (pan-herkes, demos-halk) kelimesinden gelmektedir. Bu yüzden, bir salgına pandemi denildiğinde tüm halkaların enfeksiyona maruz kalabileceği ifade edilmektedir (Coppola, 2007; TTD, 2020). Kentlerde artan nüfus yoğunluğu ve faaliyetler, insan sağlığına zarar veren biyolojik tehlikelerin ortaya çıkması için uygun koşulları oluşturmaktadır. Biyolojik tehlikelere ilişkin süreçlerin doğru yönetilmemesi durumunda, salgınlar ortaya çıkabilmekte ve tüm dünyada etkili olduklarında pandemi olarak adlandırılmaktadır (Tuğaç, 2020).

Tarihsel süreçte kentlere bakıldığında, pek çok kez salgın süreçlerinin yaşandığı görülmektedir (ör. kara veba). Bu salgınların kentlerin yapısında ve kentleşme süreçlerinde önemli değişikliklere sebep olduğu bilinmektedir. Allam ve Jones (2020), ciddi nüfus kaybıyla sonuçlanan büyük sanayileşme, iç savaş, şehir yangınları, depremler ve hastalık dönemlerinden çıkan ülkelerin, kentlerin yaşanabilirliğini artırmak için önemli kent planlama ve peyzaj tasarım stratejileri benimsediğini belirtmiştir. Örneğin, geçtiğimiz yüzyılın başında Howard'ın bahçe şehir yaklaşımı, Olmsted'in New Yorklular için yeşil akciğerler 
teorisi, Birmingham'ın yeşil kuşă̆ı, Kophenag'ın beş parmak planı ve Boston'un zümrüt kolyesi, yaşam kalitesi kaygıları ile ortaya atılmış teori ve uygulamalardir.

Salgınlar kapsamda en güncel tehdit ise, literatürde Coronavirus Disease 2019 (COVID-19) olarak anılan Koronavirüs salgınıdır. 2019 yılının son günlerinde Çin'in Wuhan kentinde başlayan salgın, Dünya Sağlık Örgütü (DSÖ) tarafından 12 Mart 2020 tarihinde pandemi olarak ilan edilmiştir. Birleşmiş Milletler (BM) Habitat'a (2020) göre, 210 ülkede 1430 şehir pandemiden etkilenmiştir. COVID-19 vakalarının \%95'i kentsel alanlarda görülmüştür. BM Kalkınma Programı (UNDP) tarafından da pandeminin küresel bir sağlık krizinden çok daha fazlası olduğu ifade edilmiştir. COVID-19 pandemisinin etkisiyle meydana gelecek değişimlerin yoğunlukla, kent planlanma, kentsel politikalar ve kentsel faaliyetlerin içeriğine ilişkin olarak gerçekleşeceği ve pandeminin önemli küresel sorunlar ortaya çıaracağı öngörülmektedir (UN Habitat, 2020; Tuğaç, 2020).

Pandemi sürecindeki ihtiyaçların en doğru şekilde analiz edilerek, kentsel mekâna yansitılması gerekmektedir. Bu bağlamda Kıygı (2020), 1/10 ile 1/1000 ölçek planlar arasındaki tutarlılığı dahi kuramayan mekânsal üretim pratikleri için bu sürecin oldukça zorlayıcı bir tecrübe olacağını ifade etmiştir.

Pandemi süreci gündelik ihtiyaçlar için, mahalle ölçeğinde erişilebilecek kentsel hizmetlerin ve açik hava ihtiyacın destekleyen kentsel yeşil alanların ne kadar hayati olduğunu bir kez daha göstermiştir. Nitekim DSÖ de sosyal mesafeyi korumak ve fiziksel aktiviteyi desteklemek adına bu süreçte aktif ulaşım türleri olan yaya ve bisikletli ulaşımın önemine dikkat çekmektedir. Bunun yanı sıra Lai vd. (2020), yeni projelendirilmiş ve mevcut toplanma alanlarının, aşırı kalabalıktan kaçınmak için (yeniden) planlanması ve spor, eğlence, rekreasyon, bisiklet, performanslar, sergiler ve siyasi toplantılar vb. açık hava etkinlikleri için küçük ya da orta büyüklükteki açık alan sistemlerinin, büyük ölçekli stadyumların ve eğlence mekanlarının yerini alması gerektiğini belirtmiştir.

COVID-19 salgınının bir sonucu olarak kamusal mekânın esnek kullanımı daha acil bir gereklilik haline gelmiş ve bu durum, farklı seyahat davranışları sebebiyle yeni bir hareketlilik morfolojisi oluşturmuştur. Pandemi sonrası dönemde senaryo, genel "hareketlilik tüketimi" (alan) ve yeni "kentsel ritimde" (zaman) beklenen azalmadır. Bu kriz, kentlerin yeniden tasarlanması için şehir planciları, peyzaj mimarları ve kentsel tasarımcilara firsatlar yaratmaktadır (Deponte, Fossa ve Gorrini, 2020; Barbarossa, 2020).

Pandemi sürecinde, temiz havada ve günışı̆̆ında olmanın enfeksiyonu ve ölüm oranlarını azaltıcı etkisi tespit edilmiştir. Bu bağlamda, ABD'de Ulusal 
Rekreasyon ve Park Kuruluşu (NRPA) tarafindan yürütülen Park Reçetesi isimli hareket oldukça dikkat çekicidir. Park Reçetesi hareketinde parkların koruyucu tıbbın bir parçası olarak kullanılması önerilmektedir (Küçükali, Küu̧ükali, ve Taşdemir, 2016).

\section{Sağlıklı Kentler}

Sağlıklı ve güvenli bir çevrede yaşamak, temel insan haklarından biridir. Türkiye Cumhuriyeti Anayasası 56. maddesine göre, "Herkes sağglklı ve dengeli bir çeorede yaşama hakkma sahiptir". DSÖ Avrupa Bölge Ofisi, Sağlıklı Kentler Projesini "Herkes için sağlık" prensiplerinin yerel seviyede uygulanmasını sağlayan bir araç olarak tanımlamaktadır. Herkes için sağlık temeline oturtularak halk sağlığına yeni yaklaşımların uygulama yöntemiyle gösterildiği bu hareket, 1986 yılında Avrupa'da seçilen 11 kent ile başlamış ve kısa sürede kıtanın 30 ülkesinde oluşturulan ulusal ağlar ile 1400 kent ve kasabaya ulaşmıştır. Zaman içerisinde hareket daha da genişleyerek küresel bir hareket niteliği kazanmıştır (Şekil 1).

"Herkes için sağlık" sloganıyla yola çıkan hareketin amaçları; (1) Kentlerin sağlıklı, temiz ve güvenli bir yerleşim yeri yaratmak üzerine deneyimlerini paylaşarak tüm vatandaşların yaşamaktan mutlu olacakları bir çevre yaratmak; (2) Eşitlik temelinden yola çıkarak din, dil, ırk, kültür, sınıf ve düşünce farkı gözetmeksizin eşit ve kaliteli bir yaşam ortamı sağlamak için sağlık, ulaşım, çevre gibi alanlarda ortak projeler geliştirmek olarak sıralanabilir.

Yapılı çevrenin sağlık davranışları ve hastalık geçişi üzerinde önemli bir etkisi vardır. Bu karmaşık bir ilişkidir ve sağlık sistemi ve bireysel davranışa odaklanan bir yaklaşımdan, yapılı çevre gibi diğer sistemlerin genişlemesine doğru evrilen bir halk sağlığı yaklaşımı olarak görülebilir (Pinheiro ve Luis, 2020). Chae ve Kim (2020) fiziksel çevrenin sağlığa etkilerini araştırdıkları çalışmalarında, kent parklarının halk sağlığına katkılarını çeşitli sağlık aktiviteleri (ör. dinlenme, spor, kültürel etkinlikler) gibi doğrudan göstergeler ve erişilebilirlik, temizlik, temiz içme suyu bulunması gibi dolayl göstergeler üzerinden incelemiştir. Ayrica COVID-19 pandemisi sonucunda artan izolasyon ihtiyacı sebebiyle, pandemi sonrası dönemde kent parkların koşullarının ve parklarda verilen hizmetlerin iyileştirilmesi de önerilmektedir. 


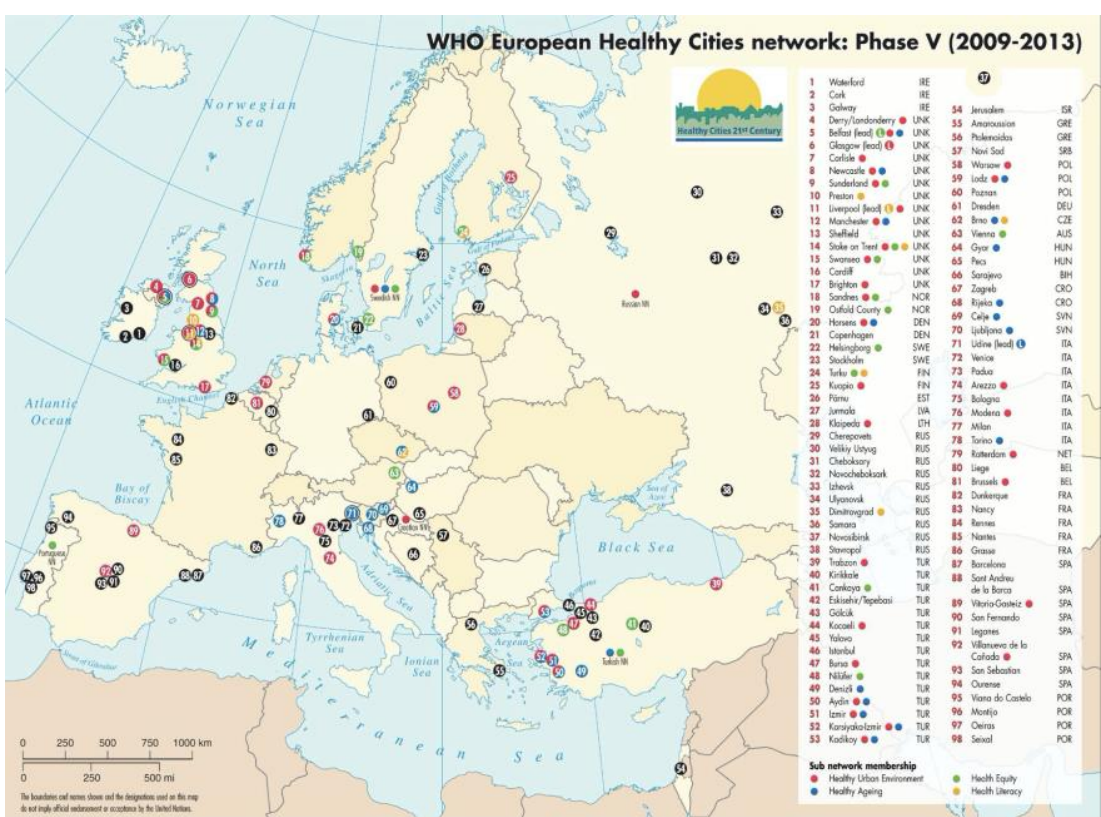

Şekil 1. DSÖ Sağlıklı Kentler Ağı, 2009-2013 (DSÖ, 2014).

Sağlıklı bir kent inşa etme sürecinde aktif kamusal kent parklarının önemli rolü, özellikle düşük gelirli ve dezavantajlı grupların bulunduğu mahallelerde park, rekreasyon alanı ve sosyal altyapı eksikliği bulunması gibi konular, kent parklarına pandemi sonrası dönemde daha dikkatlice yaklaşılması gerekliliğini ortaya koymaktadır (Joassart-Marcelli, Wolch ve Salim, 2011).

Ciddi ve Yazgan (2020), salgın sürecinde hükümetlerin halkı fiziksel aktiviteye teşvik etmesinin, sağlık uzmanlarının fiziksel aktiviteye yönelik önerilerinin ve egzersiz yapmanın, fiziksel olduğu kadar ruh sağlığını korumak açısından da gerekli olduğunu ve bireylerin orta seviyede aktivite yapmasının yaşam kalitesi üzerinde faydalı olacağını belirtmektedir. Bu sebeple, karantina döneminde evlerde ya da yetkililer tarafından izin verilen güvenli doğal ortamlarda (ör. kent ormanı) fiziksel aktivitenin teşvik edilmesi önemlidir (Chen, Mao, Nassis, Harmer, Ainsworth ve Li, 2020; Ciddi ve Yazgan, 2020).

COVID-19 pandemisi sürecinde artan sosyal izolasyon ihtiyacı, karantinalar ve buna bağlı fiziksel aktivite eksikliği, kalp-damar rahatsızlıklarına sebep olabilmektedir. Bu yüzden yasaklarda evde, diğer zamanlarda da tercihen erişilebilir mahalle parklarında egzersiz yapılması önerilmektedir (Peçanha, Goessler, Roschel ve Gualano, 2020). Doğal ortamlarda zaman geçirmenin iyileşme sürecini hızlandıracağı ve stresi ortadan kaldıracağı düşünülmektedir (Kaplan, 1995). 
Yeşil alanların insan ruh ve beden sağlığı üzerindeki etkilerini araştıran çalışmalar, kentlerde erişilebilir yeşil alan miktarının ölüm oranlarıyla ters orantılı olduğunu ortaya koymaktadır (Ward Thompson, 2011). Akpınar ve Cankurt (2015), Türkiye'de kişi başına düşen yeşil alan miktarı ile kalp krizi, doğal ölüm ve intihar olayları arasındaki ilişkiyi incelenmiştir. Araştırma sonunda kişi başına düşen yeşil alan miktarı arttıkça, kalp krizi, doğal ölüm ve intihar olaylarının gerçekleşme oranının azaldığını tespit etmişlerdir (Akpınar ve Cankurt, 2015).

İlk peyzaj mimarı olarak kabul edilen Frederick Law Olmsted, yaklaşık bir asır önce yeşil alanların insan sağlığ üzerindeki etkisi üzerinde durmuştur. Bugün özellikle gelişmiş ülkelerde, politikacılar ve halk sağlığı uzmanları, yeşil alanların insan sağlığı üzerindeki etkisine dikkat çekmektedir (Morris, Beck, Hanlon ve Robertson, 2006).

Bu bağlamda, pandemi sonrası dönemde kentlerdeki açk yeşil alan miktarlarının artırılması ve mevcut olanların yeni normal koşullara uygun olarak iyileştirilmesi gerektiği görülmektedir.

\section{Yeşil Alan Sistemleri ve Standartlarn}

Yeşil alan kavramı, 3030 sayılı Kanun kapsamı dışında kalan Belediyeler Tip İmar Yönetmeliğinde; "Toplumun yararlanması için ayrilan oyun bahçesi, çocuk bahçeleri, dinlenme, gezinti, piknik, eğlence ve kıyı alanları toplamıdır. Interpolölçekteki fuar, botanik ve hayvanat bahçeleri ve bölgesel parklar da yeşil alan kapsamındadır" şeklinde tarif edilmiştir (World Cities Culture Forum, (n.d.); Eminağaoğlu ve Yavuz, 2010).

Avrupa Komisyonu Kentsel Denetim Raporuna göre (2000), kentsel yeşil alanlara yürüme süresi ortalama 15 dakika olmalıdır. Yeşil alanların çeşitlerine göre en uygun ulaşım ve yürüme mesafeleri; çocuk bahçeleri ve oyun alanlar için $400 \mathrm{~m}$ - 10 dakika, semt-mahalle parkları için $800 \mathrm{~m}$ - 20 dakika, ve kent parkları için 1200 m - 30 dakikadır (Manlun, 2003; Altunkasa, 2004; Aydemir, 2004; Önder ve Polat, 2012).

Literatürde yeşil alanların insan ruh ve beden sağlığı üzerine ciddi olumlu etkileri olduğu sıklıkla dile getirilmektedir. Yapılan araştırmalar, kentlerde yaşayan insanların kalabalık, gürültü, açık ve yeşil alan eksikliği gibi faktörlerden dolayı, kırsal alanlarda yaşayan insanlardan farklı davranışlar sergilediğini göstermektedir (Sanisa, Lafortezza, Bonnes ve Carrus, 2006). Kuo ve Sullivan (2001) yaptıkları çalışmada, yakınında veya çevresinde ağaç olan evlerde yaşayan insanların, etrafı tamamen boş evlerde yaşayan insanlara göre, ailelerine ve çevrelerine daha az şiddet uyguladığını tespit etmiştir. Ulrich (1984), stresi 
yenmede doğal manzaraların etkili olduğunu belirtmiştir. Konuyla ilgili yaptığı bir araştırmada, hastanede odalarından ağaçları izleyebilen hastaların iyileşme süreçlerinin daha hızlı olduğunu saptamıştır (Uslu, 2007).

İnsan sağlığına birçok faydası olan parklar, sağlık sektörünün üzerine düşen yükü hafifletme potansiyeline sahiptir. DSÖ istenmeyen çevresel etkileri azaltmak için şehirlerde kişi başına en az $9 \mathrm{~m}^{2}$ yeşil alan olması gerektiğini belirtmektedir. Kent içi ve çevresinde planlı yerleştirilen açık ve yeşil alanlar kentsel kaliteyi artırmaktadır. Ancak, yeşil alanlardan optimum yararlanma ancak konum, büyüklük, ulaşılabilirlik, nitelik ve hizmet çeşitliliği gibi konularda yeterli koşulların oluşturmasıyla sağlanabilir (Önder ve Polat, 2012).

Yeşil alanların yer seçiminde mahallere dağılım ve oyun alanı, mahalle parkı, spor alanı gibi yeşil alan türlerinde denge gözetilmelidir (Önder ve Polat, 2012). Yeşil alanlar, kentsel arazi kullanım dokusu ve kent formuna uygun olarak, yeşil süreklilik içerisinde yaya ve bisiklet yolları ile entegre edilerek, sistemli bir şekilde planlanmalıdır (Emür ve Onsekiz, 2007; Eminağaoğlu ve Yavuz, 2010).

Korkut vd. (2010), açık ve yeşil alanların kent içindeki dağılımlarının ve kişi başına düşen yeşil alan miktarı ve işlevinin bir kentin açı ve yeşil alan sistemini oluşturduğunu belirtmektedir. Bu kapsamda kent içindeki park ve bahçeler, oyun ve spor alanları, meydanlar, yol ve caddeler, doğal eşikler (ör. vadiler, akarsular); ve kırsal alanlarda ormanlar, göller gibi doğal ve kültürel peyzajlar da açık ve yeşil alan sistemleri kapsamında ele alınmaktadır (Yücesu, Korkut ve Kiper, 2017).

COVID-19 pandemisi sürecinde yeşil alanların endüstri devriminde olduğu gibi kent sağlığının önemli bir bileşeni haline geldiği görülmektedir. Ancak, pandeminin olağanüstü koşullarında, kent parklarında geçmişten farklı davranış kalıplarının, sosyal mesafe ihtiyacının ve buna bağlı olarak farklı kullanıcı beklentilerinin ortaya çıktığı görülmektedir (Sayan Atanur ve Ersöz, 2020).

Dünyada kentler arasında kişi başına düşen yeşil alan standartları arasında ciddi farklılıklar gözlemlenmektedir. Örneğin yaklaşık 2 milyon nüfuslu Stockholm'de kişi başına 77 m² $^{2}$ ken, 2014 verilerine göre yaklaşık 15 milyon nüfuslu İstanbul'da kişi başına 5,67 m²yeşil alan düştüğü görülmektedir (Küçükali vd., 2016).

Ersoy (2009), Türkiye'de arazi kullanım standartlarına ilişkin yaptığı çalışmada bazı ülkelerdeki aktif yeşil alan standartları (Tablo 1); ve ABD Ulusal Rekreasyon ve Park Kuruluşunun (NRPA) 2000 yllı için hedeflediği standartları karşılaştırmıştır (Tablo 2). 
Tablo 1. Bazı ülkelerde kişi başına düşen aktif yeşil alan standartları, $\mathrm{m}^{2} /$ kişi (Ersoy, 2009 tablolarından uyarlanmıştır).

\begin{tabular}{lllllll}
\hline Yeşil Alanlar $\left(\mathbf{m}^{2} / \mathbf{k i s ̧ i}\right)$ & ABD & Almanya & İngiltere & Fransa & Hollanda & Türkiye \\
\hline Komşuluk Parkı & 10 & 5,8 & - & 5 & 3,5 & 4 \\
\hline Semt Parkı & 10 & 8 & - & - & - & 7 \\
\hline Kent Parkı & 20 & 15 & 20 & 13 & $7-9$ & 10 \\
\hline Yakın Çevre Parkı & 60 & 48 & 40 & 12 & 20 & 17 \\
\hline Bölge Parkı & 260 & 78 & - & 75 & $25-30$ & - \\
\hline Çocuk Oyun Yeri & 1 & $0,5-2,5$ & - & - & - & 2 \\
\hline Çocuk Bahçeleri & $5-6$ & - & 10 & 5 & 4 & 1 \\
\hline Spor Alanlari & - & $4,5-5$ & - & 8 & 6,5 & - \\
\hline
\end{tabular}

Tablo 1'de kişi başına düşen aktif yeşil alan standartlarının ülkeden ülkeye farklılık gösterdiği görülmektedir. Bu standartlara bakıldığında, ABD'de yer alan mahalle ve semt parkları için $\mathbf{1 0}$ m²/kişi önerilirken; büyük kent parkları için $\mathbf{2 0}$ $\mathrm{m}^{2} / \mathbf{k i s ̧ i}$, kentsel yakm çeore parkları için $60 \mathrm{~m}^{2} / \mathbf{k i s ̧ i ~ v e ~ b o ̈ l g e ~ p a r k l a r ı ~ i c ̧ i n ~} 260 \mathrm{~m}^{2} / \mathbf{k i s ̧ i}$ önerildiği görülmektedir. Buna göre, Türkiye'nin yeşil alan standartlarının tablodaki diğer ülkelere göre yetersiz olduğu söylenebilir.

Tablo 2' de gösterilen bazı ülkelerdeki yeşil alanlar ve spor alanlarına ilişkin önerilen standartlar karşılaştırıldığında, kent ölçeğinde 10-77 m²/kişi aralığı önerildiği ortaya çıkmaktadır. En yüksek yeşil alan standardına sahip şehir kişi başına 77 m² $^{2}$ yeşil alan oranıyla İsveç'in Stockholm şehridir.

Tablo 2. Bazı ülkelerde yeşil alanlar ve spor alanlarına ilişkin önerilen standartlar (Ersoy, 2009 tablolarından uyarlanmıştır).

\begin{tabular}{|c|c|c|c|}
\hline & Yerleşme Büyüklüğü & Kentsel Alana Oranı (\%) & $\mathbf{m}^{2} /$ kişi \\
\hline \multirow{3}{*}{ ABD } & Kent & - & 10,5 \\
\hline & $25.000+$ & 40,24 & 106,4 \\
\hline & $250.000+$ & 39,97 & 123,5 \\
\hline \multirow{2}{*}{ Almanya } & Kent & - & 15 \\
\hline & $600.000+$ & - & 27,3 \\
\hline \multirow{2}{*}{ İngiltere } & Kent & - & $14-21$ \\
\hline & $10.000+$ & 21,5 & 63 \\
\hline \multirow{2}{*}{ Fransa } & Kent & - & 25 \\
\hline & $100.000+$ & - & 23 \\
\hline Hollanda & Kent & - & 20,5 \\
\hline İsveç & Kent (Stockholm) & - & 77 \\
\hline Kanada & 2.000 .000 (Toronto) & 24,2 & - \\
\hline Rusya & Kent & - & 50 \\
\hline \multirow{2}{*}{ İtalya } & Roma & - & 22 \\
\hline & Küçük-Orta Kentler & - & 12,5 \\
\hline \multirow{3}{*}{ Avustralya } & Kent & - & 10 \\
\hline & Sydney & - & 19,2 \\
\hline & $80.000+$ & 9,7 & 40 \\
\hline
\end{tabular}


Türkiye'de yeşil alanlara standart getirilmesi amacıyla kişi başına düşen yeşil alan miktarları yasa ve yönetmelikler ile belirlenmektedir (Yıldızcı 1991; Eminağaoğlu ve Yavuz, 2010). Ancak, yeşil alanların nüfusa bağlı olarak kişi başına düşen miktar ile tanımlanması, yeşil alanların kent içinde her zaman yeterli miktarda yer aldığı anlamına gelmemektedir. Planlarda alan hesabı ile belirtilen yeşil alanlar, sadece sınırlarıyla değil; işlevselliği, sosyal mekân özelliği ve içinde barındırdığı doğal faktörler ile kent yaşamının organik bir parçası olarak tasarlandığı takdirde gerçek anlamın bulabilecektir. Türkiye'de yeşil alan standartlarının niceliksel hesaba dayanması, kimi zaman yolların ve refüj alanlarının "park" kapsamında değerlendirilerek kâğıt üzerinde alansal standartların sağlanması, parkların gerçek işlevi olan kentsel kalitenin artırlması hedefini gözden kaçırmaktadır (Öztürk, 2004; Eminağaoğlu ve Yavuz, 2010).

Ersoy (2009), aktif ve pasif olarak tanımladığı yeşil alanların, rekreasyon ve spor alanları, mahalle parkları, çocuk parkları, mezarlıklar, askeri alanlar, tampon bölgeler (yeşil kuşaklar) vb. birçok kullanıma sahip olup, kent merkezi ve çeperindeki konumuna göre farklı büyüklüklerde bulunabildiklerini belirtmiştir. Yeşil alanlar büyüklük ve türlerine göre, hizmet edilen nüfusun büyüklügüü, yerleşimin özellikleri, topoğrafya, doğal özellikler ve iklim koşulları gibi değişkenlere göre ülkeler ve şehirler arasında farklılık göstermektedir.

Kentsel standartlar iki gruba ayrllabilir: Birinci tür standartlar tüzel niteliktedir ve yetkili kurumlarca bu standartlara uyma zorunluluğu vardır. İkinci tür standartlar ise teknik yaklaşımlar, alışkanlıklar ve önerilerden kaynaklanmaktadır. Bu iki grubun yanı sıra, kentsel standartların diğer bir kökeni, kentlerin mevcut durumu ve gelişme eğilimine göre kent ve yapı ölçeğinde yapılan somut araştırmalardır. Kentsel yeşil alan standartları belirlenirken de kentin ihtiyaçları, nüfus, kentsel doku ve kullanım yoğunluğu kriterleri dikkate alınmaktadır (Şahin ve Barış, 1998; Önder ve Polat, 2012).

Çetiner (1972) çalışmasında, Türkiye'deki yeşil donatı türleri, hizmet ettiği kişi sayısı, büyüklüğü ve kişi başına düşen miktarlarına ilişkin veriler paylaşmıştır (Tablo 3). Bu oranlarınn günümüz verilerinden oldukça yüksek olduğu dikkati çekmektedir. Ancak Tablo 3'te yer alan yeşil donatı türleri, TÜIKK ile yapılan görüşme sonrasında, ulaşılabilecek güncel ve toplu bir veri tabanı bulunmaması sebebiyle mevcut durum ile karşılaştırılamamıştır. 
Tablo 3. Türkiye'de yeşil alan standartları (Çetiner, 1972; Ersoy, 2009 tablolarından uyarlanmiştır).

\begin{tabular}{llll}
\hline Yeşil Donatı Türleri & Hizmet ettiği kişi sayısı & Alan (ha.) & $\mathbf{m}^{2} / \mathbf{k i s ̧ i}$ \\
\hline Çocuk bahçesi & $1000-2500$ & - & $0,5-1$ \\
\hline Oyun alanı & $2500-3500$ & - & $1-2$ \\
\hline Mahalle parkı & $3500-5000$ & - & $2,5-3$ \\
\hline Şehir parkı & $25.000-35.000$ & - & $2-4$ \\
\hline Çevre parkı & $100.000-250.000$ & 40 & $1,6-4$ \\
\hline Bölge parkı & $100.000-250.000$ & 200 & $16-20$ \\
\hline Milli park & $100.000-125.000$ & 400 & $32-40$ \\
\hline Mezarlı & $1000-2500$ & - & 2,7 \\
\hline Botanik bahçesi & $100.000-125.000$ & - & - \\
\hline Mesire piknik yerleri & $25.000-35.000$ & $0-8$ & $0-3,2$ \\
\hline Spor alanları & - & - & - \\
\hline
\end{tabular}

Türkiye'de yönetmeliklerle belirlenmiş kişi başına düşen yeşil alan miktarlarına bakıldığında; İmar Planı Yapılması ve Değişikliklerine Ait Esaslara Dair Yönetmelikte (1985) kişi başına düşen yeşil alanlar $7 \mathbf{~ m}^{2}$ olarak belirlenirken, 1999 yılında yapılan değişiklikle bu standart 10 m² $^{2}$ olarak değiştirilmiş̧tir. 2014 yılında güncellenen son yönetmelikte yeşil alan standartlarına dair bir iyileştirme yapılmadığı ya da nüfus yoğunluğuna göre farklı standartlar geliştirilmediği görülmektedir. Bu durumda, 1999 yılından bugüne kadar Türkiye'de yeşil alan standartlarına ilişkin bir iyileştirme yapılmadığı görülmektedir.

3194 sayılı İmar Kanunu'nun Mekânsal Planlar Yapım Yönetmeliğine göre "sosyal açık ve yeşil alanlar" kapsamında kentte bulunabilecek kullanımlar; çocuk bahçesi, park, botanik parkı, hayvanat bahçesi, mesire yeri ve rekreasyon alanı olarak listelenmiş ve bu alanların toplam standard $10 \mathrm{~m}^{2} /$ kişi olarak belirlenmiştir. Ancak 1999 yılında yayınlanan değişiklikte 7 m²/kişi'den $10^{2}$ $\mathbf{m}^{2} /$ kişi'ye çıkarılan açık ve yeşil alan standardı, kullanım alanları bakımından Tablo 4'teki gibi dağılım gösterirken (Aksoy, 2014); Mekânsal Planlar Yapım Yönetmeliğinde (2014) bu ayrım yapılmayarak, sadece toplam standart büyüklük belirtilmiştir.

Tablo 4. 02.09.1999 tarihli yönetmelikte yeşil alan standartları $\left(\mathrm{m}^{2} / \mathrm{kişi}\right)$

\begin{tabular}{lllll}
\hline Çocuk Oyun Alanı & Mahalle Parkı & Kent Parkı & Spor Alanı & Toplam \\
\hline 1,5 & 2 & 3,5 & 3 & $\mathbf{1 0}$ \\
\hline
\end{tabular}

Ülkemizde yeşil alan standartları genellikle kişi başına düşen yeşil alan miktarı şeklinde niceliksel bir yaklaşım ile belirlenmektedir. Aynı yönetmelikte, belediye olan yerlerde nüfus ne olursa olsun kişi başına düşen aktif yeşil alan miktarı, $\mathbf{1 0} \mathbf{~ m}^{2}$ olarak ifade edilmektedir. Ancak bu niceliksel yaklaşım yeterli değildir. Yeşil alan standartlarının saptanmasında, kentin fiziki çevre özelliklerinin yanında (iklim, topografya, kentin konumu vb.), sosyo-kültürel faktörler, 
ekonomik faktörler ve kullanım yoğunluğu da önemli rol oynamaktadır. Kent içindeki işlevlerini yerine getirebilmeleri için yeşil alanların nitelik ve nicelik olarak yeterli olmasının yanı sıra, erişilebilir olması da önemlidir (Eminağaoğlu ve Yavuz, 2010).

Bu standartlar yeterli olmamakla birlikte, Türkiye'nin birçok kentinde $\mathbf{1 0}$ $\mathbf{m}^{2} /$ kişi yeşil alan standardına ulaşılamadığı görülmektedir. Güncel yönetmelikte belirtilen standartlarda işlevsel kullanım-büyüklük ilişkisini tanımlayan herhangi bir yönlendirici olmaması ve yeşil alan hesaplanmasına ilişkin bir kriter belirtilmemesi sebebi ile bazı kentlerde pasif yeşil alanların hesaplamaya katılması yoluyla yeşil alan miktarını yüksek gösterme kaygısı göze çarpmaktadır. Özellikle pandemi sonrası dönemde artan kentsel açık yeşil alan ihtiyacı düşünüldügünde, aktif kullanıma uygun ve işlevsel yeşil alan standartlarının yeniden gözden geçirilmesi gerektiği görülmektedir.

İhtiyaç duyulan kentsel yeşil alanların büyüklükleri bireylerin boş zaman alışkanlıkları ile doğrudan ilgilidir. Boş zamanlarda bireylerin etkinlik seçimi ise gelir düzeyi, yaş, cinsiyet, meslek, çalışma saatleri ve yoğunluğu ve toplumsal değerler ile ilişkilidir. Ayn zamanda bu tercihleri etkileyen çevresel olanaklar, erişilebilirlik ve iklim gibi dış faktörler de mevcuttur. Bu tercihlerin zamana ve içinde bulunulan şartlara bağlı olarak değişebileceği de unutulmamalıdır. Boş zaman alışkanlıkları dışında parkın potansiyel kullanıcı sayısı, bu kullanıcıların kullanım sıklığı, parkın işlevi ve çeşitliliği de büyüklüğü etkileyen faktörler arasındadır (Aydemir vd., 1993; Gedikli, 2002).

Gedikli (2002), kişi başına ihtiyaç duyulan optimum yeşil alan büyüklüğünü hesaplarken, parka gitme sıklığı, parkta geçirilen süre, parka gitme gerekçesi, mevsimsel tercih değişiklikleri, parkın yoğun saatleri, bireylerin ve grupların bir kamusal mekân olarak yeşil alanlarda sosyalleşme eğilimleri, mahremiyet için ihtiyaç duyulan uzaklık ve ortalama grup büyüklüğü faktörlerini dikkate almıştır. Kişi başına düşmesi gereken yeşil alan büyüklüğü belirlenirken öne çıkan faktörlerin ihtiyaç duyulan bireysel sosyal alan büyüklüğü ve grup büyü̈klüğ̈̈ olduğu görülmektedir. Normal şartlar altında kişi başına düşen sosyal alan büyüklüğü 40-50 cm yarıçaplı bir daire kabul edilmektedir (Gehl, 1987). Bir sonraki önemli kriter ise kullanım sıklı̆̆ıdır (Gedikli, 2002).

Yapılan çalışmada, pandemi sonrasında kişi başına düşen optimum yeşil alan büyüklüğünü hesaplanırken, Gedikli (2002) tarafından önerilen hesaplama modelinin faktörleri pandemi koşullarına uyarlanmıştır. Bu modelin ele alınmasının öncelikli sebebi parametrelerinin sosyal mesafe tercihleri ve kullanım sıklı̆̆ına bağlı olmasıdır. Kişisel tercihlerin ötesinde sağlıklı kalabilmek için COVID-19 sürecinde zorunlu bir politika haline gelen sosyal mesafe önlemleri 
bu modele uyarlanabilir niteliktedir. Karantina süreçleri ve sosyal hayat kısıtlaması ile birlikte kamusal mekân kullanımının erişilebilir yeşil ve açık alanlara yönelmesi ve haftanın belli saatlerini egzersize ayırma ihtiyacı, pandemi döneminde kullanım sıklığını oluşturan faktörleri belirlemiştir.

\section{Yöntem ve Bulgular}

Çalışmada öncelikle, pandemi sonrası dönemde kentsel alanlar, sağlıklı kentler, yeşil alan sistemleri ve standartlarına ilişkin yapılan literatür taraması ardından, dünyada ve Türkiye'de yeşil alan standartları karşılaştırılmış ve pandemi sonrası dönemde ortaya çıan ihtiyaçlar doğrultusunda, kişi başına düşen optimum kentsel yeşil alan miktarına ilişkin hipotetik bir model önerilmiştir.

PS-YA (Pandemi Sonrası Yeşil Alanlar) Modeli olarak adlandırılan model, Gedikli (2002) ve Aytatlı (2013) tarafından kentsel açı yeşil alan standartlarının niceliksel olarak belirlenmesinde önerilen matematiksel modeller üzerinden geliştirilmiştir.

Bu kapsamda, pandemi sonrası dönemde kamusal açı ve yeşil alanlar üzerinden optimum yeşil alan standartları belirlenerek, ileride yapılacak araştırmalar için bilimsel bir altlık oluşturulması ve kentsel yeşil alan standartlarının iyileştirilmesi amaçlanmıştır.

\section{PS-YA Modeli}

Yapılan çalışma, pandemi sonrası dönemde sosyal izolasyon ihtiyacı sonucunda ortaya çıkan yeni normal standartlara göre kentlerde ihtiyaç duyulan açık ve yeşil alan miktarlarını hesaplamaya yönelik hipotetik bir model önermektedir.

PS-YA Modeli oluşturulurken, kentsel açı yeşil alan standartlarının niceliksel olarak belirlenmesine yardımc olacak matematiksel modeller incelenmiş, Gedikli (2002) ve Aytatlı (2013) tarafından yapılan ve alan çalışmaları ile desteklenmiş yöntemler temel alınmıştır. Bu örnek çalışmalar, kişisel sosyal mesafe, gruplar arası istenen mesafe ve yeşil alanın kullanım sıklığını dikkate alarak matematiksel modeller oluşturmuş ve bu yöntemle kişi başı birim yeşil alan ihtiyacını belirlemiştir.

Modelde kullanılan formüller;

$$
A=\frac{\pi}{n}\left[\frac{X}{2}+r_{1}\left(1+\frac{1}{\sin \frac{\pi}{n}}\right)\right]^{2}
$$


A: Grup içinde bir kişi başına düşen sosyal alan büyüklüğü $\left(\mathrm{m}^{2} / \mathrm{kişi}\right)$

n: Grup büyüklüğü (kişi sayısı)

X: İki grup arasındaki uzaklık (mahremiyet/sosyal mesafe) (m)

r1: bir kişinin kapladığı sosyal alan yarıçapı (m)

$$
\alpha=\sum \beta \cdot P
$$

$\alpha$ : Mahalle parkına yıl boyunca en yoğun gün ve en yoğun kullanım diliminde gelen kişi sayısı

$\beta$ : Park kullanım sıklı̆̆ katsayısı

P: Belirli bir sıklıkta kullanan kişi sayısı

$$
A_{p}=\alpha \cdot A
$$

Ap: Kişi başı mahalle birim alan büyüklüğü $\left(\mathrm{m}^{2} / \mathrm{kişi}\right)$

$\alpha$ : Mahalle parkına yıl boyunca en yoğun gün ve en yoğun kullanım diliminde gelen kişi sayısı

A: Grup içinde bir kişi başına düşen sosyal alan büyüklüğüu $\left(\mathrm{m}^{2} / \mathrm{kissi}\right)$

Yapılan çalışmada kişi başına ihtiyaç duyulan birim mahalle parkı büyüklüğü, merkezinde bir park bulunan $\mathbf{1 0 . 0 0 0 ~ k i s ̧ i l i k ~ h i p o t e t i k ~ b i r ~ m a h a l l e ~ u ̈ z e r i n - ~}$ den kurgulanmıştır. Çalışma kapsamında belirlenen bu hipotetik mahalle, pandemi koşulları çerçevesinde değerlendirilmiştir.

Hipotetik mahalle nüfusu belirlenirken, Clarence Perry (1974) tarafindan kurgulanan "komşuluk birimi" yaklaşımı esas alınmıştır. Bu yaklaşım merkezine bir ilkokulu alan, ilkokul çağındaki bir çocuğun rahatlkkla yürüyerek okula gidip gelebileceği büyüklükte, nüfusu yoğunluğa göre değişkenlik gösterebilecek yerleşim birimini tariflemektedir. Daha açık bir ifade ile merkezinde ilkokul birimi olan $\mathbf{4 0 0} \mathbf{m}$ yarıçapında yerleşim alanları komşuluk birimi olarak tanımlanmıştır. Buradan yola çıkarak hipotetik olarak merkezinde yeşil alan bulunan ve $\mathbf{4 0 0} \mathbf{m}$ yarıçapında yaklaşık 48 ( $\cong 50)$ ha bir yerleşim birimi ele alınmiştır.

Kentsel yoğunluk olarak Mekansal Planlar Yapım Yönetmeliğinde verilen yoğunluk değerleri dikkate alınarak orta yoğunlukta bir yerleşim kurgulanmıştır (meskun alan için $151 \mathrm{k} / \mathrm{ha}$ - $300 \mathrm{k} / \mathrm{ha}$; gelişme konut alanı için $121 \mathrm{k} / \mathrm{ha}$ - 251 k/ha). Mevzuatta belirtilen orta yoğunluk değerini ifade etmek üzere bu hipo- 
tetik alanın yoğunluğu 200 kişi/ha ve nüfus büyüklüğü 10.000 kişi olarak belirlenmiştir. Bu nüfus büyüklüğü literatürde tanımlanan bir komşuluk birimi (mahalle) için belirlenen nüfus büyüklüğü aralıkları ile tutarlıdır.

Daha açık bir ifade ile, Perry (1974) komşuluk için 3000-12.000 nüfus aralığı önerirken, Chicago planında (1942) komşuluk birimleri 4000-12.000 nüfus büyüklüğünde, Londra planında ise (1944) 6000-10.000 nüfus büyüklügünde tasarlanmıştır (Barlas, 2012). Bunun yanı sıra Alexander (1977), ancak 5.000 ila 10.000 nüfuslu topluluklarda bireyin bir sesi olabileceğinden bahsederek dolaylı yoldan komşuluk birimlerinin ideal nüfus büyüklüğüne dair bir söylem oluşturmuştur. Tüm bunlara dayanarak hipotetik çalışma alanının nüfus büyüklüğü 10.000 kişi olarak belirlenmiştir.

Pandemi döneminde belirlenen kısıtlar ve sağlık açısından önemi sıklıkla vurgulanan sosyal mesafe ihtiyacı dikkate alınarak "bir kişinin kapladığı sosyal alan yarıçapı ( $r$ )" (iki kişi arası mesafe) $\mathbf{2}$ m olarak belirlenmiştir (Şekil 2).

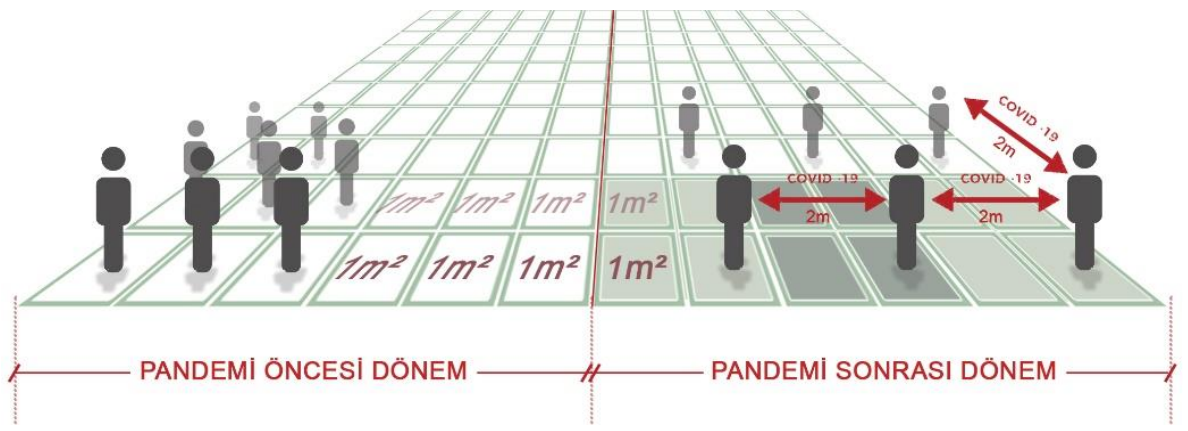

Şekil 2. Pandemi öncesi ve sonrası dönemde iki kişi arası minimum mesafe.

Bu dönemde birçok ülkede iki kişiden daha büyük grupların kamusal alanda bir araya gelmesi yasaklandığı için, "grup büyüklüğüu (n)" 2 kişi olarak belirlenmiştir. Yine sosyal mesafe dikkate alınarak "iki grup arasındaki uzaklk (X)" $4 \mathrm{~m}$ alınmıştır (Şekil 3).

Örnek alınan çalışmalarda "mahalle parkına yıl boyunca en yoğun gün ve en yoğun kullanım diliminde gelen kişi sayısı ( $\alpha$ )" yapılan anketler ile ortaya konulmuştur. Ancak örnek çalışmalardan farklı olarak bu çalışmanın yöntemi oluşturulurken herhangi bir kentsel alanda yaşayan kişilerin bireysel tercihleri değil; pandemi döneminde ortaya çıkan gereklilikler, yeni normaller ve kentsel alanda alınması gereken önlemler ile sağlık kurumlarının toplum sağlığı açısından yaptığı öneriler dikkate alınmıştır. Bu bağlamda, kişiler arası sosyal mesafe ve yeşil alan kullanım sıklığı pandemi koşullarının kentli hayatına dayat- 
mış olduğu yeni standartlar üzerinden belirlenmiştir. Bu yöntemin tercih edilmesinin bir diğer sebebi ise pandemi sürecinde yerel halk ile anket veya görüşme yapmanın taşıdığı risklerdir. Belirtilen bu sebeplerden dolayı anket veya görüşme yerine belirlenen sayısal kabuller üzerinden PS-YA Modeli uygulanmiştır.

Sağlıklı bir yaşam ve sağlıklı birey için uzmanlar tarafından tavsiye edilen egzersiz/açı alan kullanım sıklı̆̆ dikkate alınmıştır.

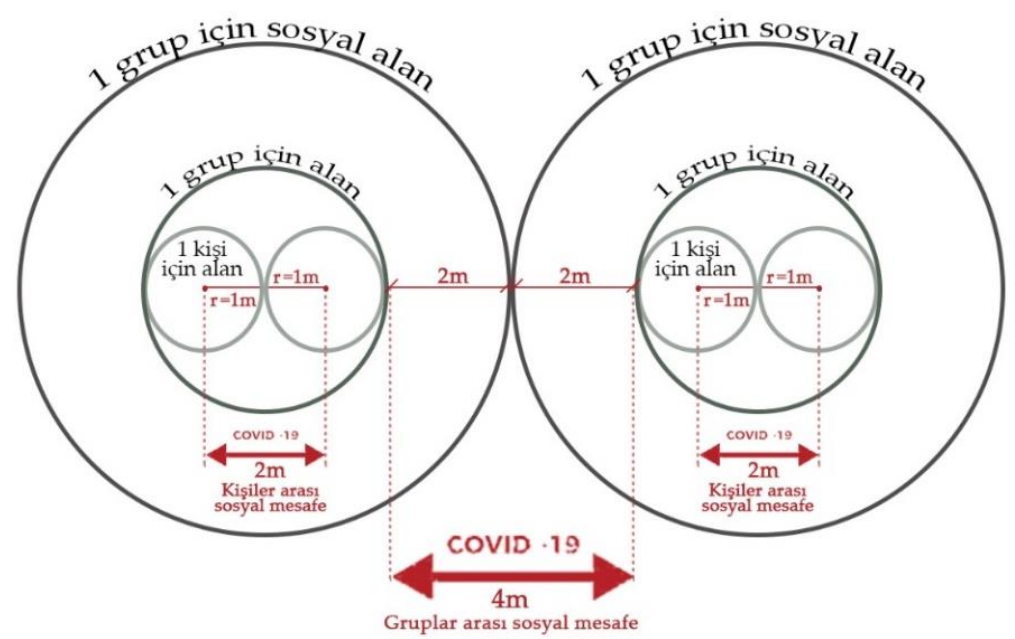

Şekil 3. Kişi ve gruplar arası belirlenen sosyal mesafe.

Bu kapsamda uzmanlar bir bireyin sağlıklı yaşam sürdürebilmesi için günde yarım saat veya haftada en az 3 kez (toplamda 150 dakika) yürüyüş/egzersiz vb. faaliyetlerde bulunmasın tavsiye etmektedir. Pandemi döneminde kapalı spor alanları risk oluşturması sebebiyle öncelikli olarak tercih edilmemekte, bu ihtiyaçlarını açı alan kullanımı ile giderilmesi tavsiye edilmektedir. Dolayısı ile ele alınan hipotetik mahallede insanların haftada minimum 3 gün yeşil alanı kullandığı varsayılmıştır. Bu varsayım ile modelde "park kullanım sıklı̆̆ katsayısı ( $\beta)^{\prime \prime}$ değişkeni 0,47 olarak belirlenmiştir (Haftada 3 gün ise $3 / 7=0,47)$. Belirlenen değerler modelde yerlerine konularak kişi başına düşen birim yeşil alan miktarı hesaplanmıştır (Tablo 5).

Oluşturulan senaryoya göre $\mathbf{1 0 . 0 0 0}$ kişinin yaşadığı bir mahallede, her birey haftanın 3 günü mahalle parkını kullanırsa kişi başı 10,8 $\mathrm{m}^{2}$ birim büyük-

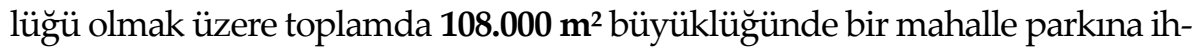
tiyaç olduğu sonucuna ulaşılmıştır. Yönetmelikte belirtilen büyüklükler arasındaki oranlar temel alınarak PS-YA Modeli sonucunda hesaplanan mahalle 
parkı birim büyüklükleri kent bütününe oranlandığında kent bütününde Tablo 6'da görülen yeşil alan ihtiyacı ortaya çıkmaktadır.

Tablo 5. PS-YA Modeline göre mahallede kişi başına düşen yeşil alan miktarı.

\begin{tabular}{ll}
\hline Değişkenler & Değerler \\
\hline $\mathrm{r} 1$ & $1 \mathrm{~m}$ \\
$\mathrm{X}$ & $4 \mathrm{~m}$ \\
$\mathrm{n}$ & 2 kişi \\
$\mathrm{A}$ & $25,13 \mathrm{~m}^{2} /$ kişi \\
$\alpha$ & 0,43 \\
Ap (kişi başı park ihtiyacı) & $\mathbf{1 0 , 8} \mathbf{~ m}^{2} / \mathbf{k i s ̧ i}$ \\
\hline
\end{tabular}

Tablo 6. PS-YA Modeline göre kent bütününde kişi başına düşen yeşil alan miktarı ( $\left.\mathrm{m}^{2} / \mathrm{kişi}\right)$.

\begin{tabular}{llllll}
\hline & Mahalle Parkı & Çocuk Oyun Alanı & Kent Parkı & Spor Alanı & Toplam \\
\hline Yönetmelik & 2 & 1,5 & 3,5 & 3 & 10 \\
PS-YA Modeli & 10,8 & 8,1 & 18,9 & 16,2 & $\mathbf{5 4}$ \\
\hline
\end{tabular}

Model sonucunda pandemi ile ortaya çıkan izolasyon ihtiyacı ve yeni normallere uyum bağlamında kent bütünü değerlendirildiğinde, 10,8 m²/kişi mahalle parkına, 8,1 m²/kişi çocuk oyun alanına, 18,9 m²/kişi kent parkına, 16,2 m²/kişi spor alanına ve toplamda $\mathbf{5 4} \mathbf{~ m}^{2} / \mathbf{k i s ̧ i}$ açık ve yeşil alana ihtiyaç duyulduğu tespit edilmiştir.

Mevcutta yasada belirtilen $\mathbf{1 0} \mathbf{~ m}^{2} / \mathbf{k i s ̧ i ~ s t a n d a r d ı n ı ~ b i l e ~ s a g ̆ l a y a m a y a n ~ k e n t - ~}$ lerin pandemi döneminde sağlıklı kentsel çevreler oluşması açısından oldukça eksik kaldığı görülmektedir. Model sonucunda, yönetmelikte belirtilen standardın ise yüksek yaşam kalitesi sunan sağhlklı kentler oluşturulması bakımından yetersiz olduğu ve kentsel açık yeşil alan standartlarının tekrar gözden geçirilmesi gerekliliği ortaya çımaktadır.

\section{Tartışma ve Sonuç}

Dünyadaki karasal alanların \%3'ünü kaplayan kentlerin birbiriyle etkileşimi önemli küresel ekonomik, ekolojik ve sosyal sonuçlar doğurmaktadır. COVID19 pandemisinin de özellikle kentlerde yaşam biçimlerini etkileyecek düzeyde önemli sonuçları olduğu ve olacağı öngörülmektedir (UNDP, 2020; UN Habitat, 2020; Tuğaç, 2020).

COVID-19 pandemisi, yeşil alanları açk tutmanın faydaları ve bu alanların yoğun kullanımlarından kaynaklanabilecek halk sağlığı riskleri arasında hükümetleri seçim yapmaya zorlamaktadır. Pandemi süresince kimi bölgelerde çocuk oyun alanlarına, parklara ve rekreasyon alanlarına erişim kapatılmıştır. Açık ve yeşil alanların ruhsal ve fiziksel sağlık ve sosyal uyum üzerinde olumlu etkileri vardır. Ancak pandemi süreci, yoğun nüfus toplanmalarında bulaş ris- 
kinin artması bağlamında, kentlerin yoğun nüfus alanlarındaki yeşil alan yetersizliğini gözler önüne sermiştir. Ayrıca, büyüklük ve kalite açısından parklara erişimle ilgili eşitsizlikler de görünür hale gelmiştir. Bu durumun önlenmesi için, kentsel peyzaj alanları, boyutları, kalitesi ve yeşil alan koridorlarının haritası çkarılmalı ve insanları doğa ile buluşturmaya yönelik çalışmalar yapılmalıdır (ör. ağaçlandırma, yeşil alanlarla bütünleşmiş yaya ve bisiklet yolları, yeni mahalle parkları). Bu girişimler, sağlıklı kentler yaratılmasının da önünü açacaktır.

Yapılan çalışmalarda, gelecekte benzeri salgın tehditlerine hızlı tepki verebilecek kadar dirençli kentler planlanması gerekliliği konusunda bir fikir birliği olduğu görülmektedir (Barbarossa, 2020; Allam ve Jones, 2020; İnal Çekiç, 2020; Kıyg1, 2020; Lai vd., 2020; Maxwell, 2020; Pinheiro ve Luis, 2020; Pisano, 2020; Tuğaç, 2020). Ancak, buna hazırlık sürecinin nasıl şekilleneceği henüz belirsizdir. Pandemi sonrası dönemde kentsel stratejileri tanımlamak ve değerlendirmek için bir araştırma çerçevesi oluştururken dikkate alınması gereken faktörler belirlenerek tartışma alanı geliştirilmelidir (Pisano, 2020). Kentler planlanırken krizlerin firsata çevirebileceği öngörüsüyle hareket etmek gereklidir. Bu bağlamda kentte, yeniden tarif edilmesi gereken sinırlar ve tanımlar ortaya çıkmaktadır. Bu süreçte faktörleri iyi analiz etmek ve önceliği sağllklı kentler ve insanlar olarak belirlemek önemlidir.

Küresel ölçekte COVID-19 pandemisinin "yeşil ilkelere" uygun bir "kentsel devrim" yaratma potansiyeli olduğu düşünülmektedir. Bu bağlamda Barbarossa (2020), yeşil yeni düzene dayal kentsel devrim için sokakların, meydanların, parkların ve insan ölçeğindeki diğer kamusal mekanların yeniden organize edilmesi, sürdürülebilir hareketlilik planları uygulanması ve komşuluk yaşamının teşvik edilmesi gerektiğini belirtmektedir.

Kentler, salgınlar vb. afetlere karşı direnci artırmayı önceleyen uzun vadeli hedeflerle ilişkilendirilerek yeniden inşa edilmelidir. Buradan hareketle, $A v-$ rupa Kentsel Şartı yeniden gündeme getirilerek, bir kez de sağlıklı yaşam alanları perspektifinden "kent hakkı" talep edilmelidir. Planlama perspektifinden pandemi sonrası dönem, sermaye odaklı mekânsal yaklaşımlar yerine; kamusal mekanları ve kentliyi ön plana alan, sürdürülebilir ulaşım seçeneklerini destekleyen yaklaşımları teşvik etmeli ve kent hakkı talebi için yeniden bir fırsat yaratmalıdır. Bu süreçte, kent hakkı talebinin ayrılmaz bir parçası olan katılımcı karar verme mekanizmalar da unutulmamalıdır.

COVID-19 pandemisi kapsamında kentsel mekânda giderek artan izleme/denetleme sistemleri (monitoring) altyapısı, devletin vatandaşlarını gözetlediği bir sistem olmaktan çıkarılıp; aslında olması gerektiği gibi, vatandaşların 
eğilim ve taleplerinin toplandığı katılımcı bir yönetişim mekanizmasına dönüştürülmelidir (İnal Çekiç, 2020).

Yeşil alanların kentin gelişiminde etkili olması, ancak sistematik bir oluşum göstermesi ile mümkün olabilir. Ayrıca kentlerin düzenli ve sağlıklı bir çevreye kavuşabilmesi, açı ve yeşil alanların kent içindeki dağılımları, büyüklükleri, işlevsel ve estetik niteliklerine bağlıdır. Açık ve yeşil alan sistemleri kentlerin özellikleri dikkate alınarak bütüncül bir sistem içerisinde kurgulanmalıdır (Aydemir, 2004; Eminağaoğlu ve Yavuz, 2010).

COVID-19 bugüne kadar süregelmiş ve bu süreçte yoğun eleştirilere maruz kalmış kentsel yönetim ve mekânsal biçimlenişi farklı bir açıdan sorgulatırken değişimin ne kadar acil bir gereklilik olduğunu da ortaya çıkarmıştır. Mevcut kentlerin "yeni normal" olarak adlandırılan pandemi döneminin gerekliliklerini karşılamakta yetersiz kaldığı, kentlilere sağlıklı ve kaliteli bir kent yaşamı sunmak için mekânsal düzenlemelere gidilmesi gerekliliği açıktır.

Yapılan çalışma, yaşam kalitesi yüksek sağlıklı bireylerin yaşadığı sağlıklı kentler inşa edilebilmesi için en önemli kriterlerden biri olan kentsel açık ve yeşil alanlar için hipotetik bir hesaplama modeli (PS-YA) önermiştir. PS-YA Modeline göre, pandemi sonrası dönemde kentlerde minimum $54 \mathbf{~ m}^{2} / \mathbf{k i s ̧ i}$ açık ve yeşil alana ihtiyaç duyulduğu tespit edilmiştir. Dolayısıyla, mevcut yönetmelikte be-

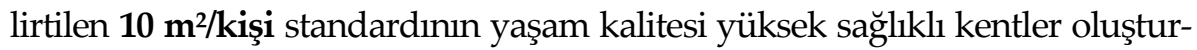
mak bakımından yetersiz olduğu ve kentsel açık ve yeşil alan standartlarının tekrar gözden geçirilmesi gerekliliği ortaya çıkmaktadır.

PS-YA Modelinin önerdiği miktar ile mevcut yönetmelikte yer alan kişi başına düşen kentsel yeşil alan miktarının birbirinden uzaklığının özellikle pandemi sürecinde kentliler üzerindeki olumsuz etkileri görülmektedir. Model sonucuna göre mevcuttaki standartlar sağlanmış olsa bile açik ve yeşil alanlarda bireylerin ihtiyaç duyduğu sosyal mesafeyi bulamayacağı, bu alanlarda salgından sakınmak için ihtiyaç duyulan temel önlemin alınmasının mümkün olmadığı ortaya çıkmaktadır. Sağlıklı bireyler için gerek sosyal mesafe gerekse ihtiyaç duyulan fiziksel aktivite sıklığı kriterlerinin sağlanamadığı bir ortamda sağlıklı kentlerden bahsetmek mümkün değildir. Bu çalışma pandemi döneminde özellikle Türkiye kentlerindeki yeşil alan eksikliğini niceliksel olarak ortaya koyarken, Sağlıklı bir toplum ve sağlıklı bir kent için gereken optimum kamusal yeşil alan büyüklüğü ile ilgili de bir öneri getirmektedir. Önerilen 54 $\mathbf{m}^{2} / \mathbf{k i s ̧ i}$ açık ve yeşil alan miktarı ilk başta ütopik görünse de dünya örnekleri

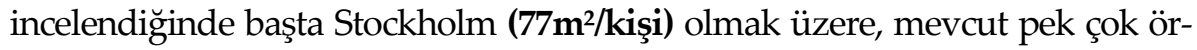
nekten düşük bir rakam olduğu unutulmamalıdır. 
Günümüzde yönetmelikte geçerli olan $\mathbf{1 0} \mathbf{~ m}^{2} / \mathbf{k i s ̧ i ~ s t a n d a r d ı n ı ~ b i l e ~ s a g ̆ l a y a - ~}$ mayan kentlerin pandemi sonrası dönemde sağlıklı kentsel çevrelerin oluşturulması için oldukça eksik kaldığı görülmektedir. Kentsel açık ve yeşil alanların nicelikleri kadar nitelikleri ve erişilebilirlikleri bağlamlarında da detaylıca incelenebilmesi için, ileride yapılacak çalışmalarda PS-YA Modelinin seçilen sahalarda yapılacak detaylı incelemeler ardından uygulanması; ve açık ve yeşil alan standartlarına yönelik hesaplama modellerinin, kentsel yeşil kuşak planlamasının ve karakteristik topluluk (mahalle) birimleri üzerinden kentsel tasarım uygulamalarının Türkiye kentsel planlama ve tasarım süreçlerinde yaygınlaştırılması önerilmektedir.

Pandemi sonrası dönemde, kentlerde "yeni normal" standartlar belirlenirken, nicelik, erişilebilirlik ve nitelik açlarından oldukça yetersiz olan kentsel açık ve yeşil alanların (yeniden) tasarlanması sürecinde, yeşil alt yapı stratejileri, kent bahçeleri, topluluk bahçeleri ve gerilla bahçecilik gibi taktiksel kentleşme uygulamaları ve müşterekler ve kent hakkı perspektifinden de ele alınması gerekmektedir. 


\title{
Extended Abstract
}

\section{Rethinking the Need for Urban Green Space Per Capita in the Post-Pandemic Era}

\author{
Sinem Özdede \\ Dalya Hazar Kalonya \\ Aysun Aygün \\ ORCID: 0000-0002-6887-085X \\ ORCID: 0000-0003-0075-0234 \\ ORCID: 0000-0002-9403-7124
}

The COVID-19 pandemic has profoundly affected daily life practices due to the need for social distance in the urban area, as in all areas of life. In this period, the importance of urban open spaces and streets was understood; and the diversity, adequacy and quality of daily activities taking place in urban open spaces and parks have started to be discussed again. The need for social isolation emerged in the pandemic era and the scarcity of urban public and open green spaces have been effective in keeping the city dwellers in their homes. On the other hand, cities with more open green spaces have provided the mobility of city dwellers since people interact less with each other. In addition, it is observed that people avoided public transportation and preferred individual transportation routes in this period. People who cannot drive private vehicles have turned to walking and cycling alternatives. This situation has once again revealed the need for accessible open spaces, green corridors and bicycle paths in cities; and lead the city planners and landscape architects to research how to create more sustainable and healthy cities.

In Turkey, Spatial Plans Building Code of the Zoning Law No. 3194 determined the green area standard per capita as $10 \mathrm{~m}^{2}$. However, the recent need for social distance brought by the new normal standards of the post-pandemic era also affected the size of the social space per person. In this context, the study aims to minimize the risks related to the COVID-19 pandemic and other factors, increase urban mobility and accessibility by focusing on the individual "green" modes of transportation such as cycling and walking in order to re-establish the public health. For this purpose, the authors propose a 
hypothetical model that calculates the amount of green space per capita according to the new normal standards.

The literature part of the study consists the titles of "Urban Areas in the Post-Pandemic Period", "Healthy Cities" and "Green Area Systems and Standards". In this context, the emergence of pandemics, the precautions to be taken, the formulas of creating healthy cities and the national and international green space standards are discussed in detail.

In the methodology of the study, a hypothetical model was proposed regarding the optimum amount of urban green space per capita in line with the needs that emerged in the post-pandemic era. The model called PS-YA (PostPandemic Green Spaces) was developed based on mathematical models proposed by Gedikli (2002) and Aytatl (2013) for the quantitative determination of urban open green space standards. In this context, it is aimed to establish a scientific base for future research and to improve urban green space standards by determining the optimum green space standards over public open and green spaces in the post-pandemic era.

In the study, the size of the neighborhood park unit needed per person was fictionalized on a hypothetical neighborhood of 10,000 people with a park in the center. This hypothetical neighborhood determined within the scope of the study was evaluated within the framework of pandemic conditions. The formulas used in the model were; radius of the social area occupied by a person, size of the social area per person in the group, distance between the groups, number of people who come to the neighborhood park on the busiest day and peak use throughout the year, frequency of park use coefficient, number of people who use it at a certain frequency, person unit area size per neighborhood ( $\mathrm{m}^{2} /$ person), number of people coming to the neighborhood park on the busiest day and the most intense usage period throughout the year, and the size of the social area per person in the group $\left(\mathrm{m}^{2} /\right.$ person). The determined values were placed in the mathematical model and the amount of new green area per person was calculated.

As a result of the model, when evaluated as a whole in the city in terms of the need for isolation that emerged with the pandemic and adaptation to the new normal, it has been determined that there is a need for a total of $54 \mathrm{~m}^{2} /$ person in the open and green space. When examined in detail, this number consists of $10.8 \mathrm{~m}^{2} /$ person is the neighborhood park, $8.1 \mathrm{~m}^{2} /$ person is the children's playground, $18.9 \mathrm{~m}^{2} /$ person is the city park and $16.2 \mathrm{~m}^{2} /$ person is the sports area. It is seen that the cities in Turkey cannot even meet the $10 \mathrm{~m}^{2} / \mathrm{pp}$ 
standards specified in the current law and are quite lacking in terms of creating healthy urban environments during the pandemic era.

The negative effects of the distance between the amount suggested by the PS-YA Model and the amount of urban green space per capita in the current regulations, especially during the pandemic era, are observed. According to the model, it turns out that even if the current standards are met, individuals will not be able to find the required social distance in open and green areas, and it is not possible to take the basic measures needed to avoid the pandemic in these areas. It is also not possible to talk about healthy cities in an environment where both social distance and physical activity frequency criteria are not met for the healthy individuals. While this study quantitatively reveals the lack of green spaces during the pandemic era, especially in the cities of Turkey, it also suggests the optimum size of green space required for a healthy city.

For further studies, implementation of the PS-YA Model in selected areas is suggested in order to examine the urban open and green areas in detail, in terms of their quality and accessibility as well as their quantity. Also, proliferation of the calculation models for open and green space standards, urban green belt planning and urban design practices over characteristic community (neighborhood) units in urban planning and design processes is crucial.

\section{Kaynakça/References}

Akpınar, A. ve Cankurt, M. (2015). Türkiye'de kişi başına düşen yeşil alan miktarı ile ölüm oranı arasındaki ilişkinin incelenmesi. Journal of Adnan Menderes University Agricultural Faculty, 12 (2), 101-107.

Aksoy, Y. (2014). Türkiye'de yeşil alanlarla ilgili yasal düzenlemeler. İstanbul Ticaret Üniversitesi Fen Bilimleri Dergisi, 13(26), 1-20.

Allam, Z. ve Jones, D. S. (2020). Pandemic stricken cities on lockdown. Where are our planning and design professionals [now, then and into the future]?. Land Use Policy, 97, 104805.

Altunkasa, M. F. (2004). Adana'nun kentsel gelişim süreci ve yeşil alanlar. Adana Kent Konseyi Çevre Çalışma Grubu Bireysel Raporu, s. 17, Adana.

Aydemir S. vd. (1993). Konut alanları donatı standartları, Doğu Karadeniz Bölgesi'nde nitelikli konut araştırması, Cilt 1. DPT. KTÜ, Trabzon.

Aydemir, S. (2004). Bölüm 12: Planlama ve planlamanın evrimi. Aydemir, Ş., Erkonak Aydemir, S., Beyazlı, D., Ökten, N., Öksüz, A.M., Sancar, C., ... Aydın Türk, Y. (Ed.), Kentsel Alanlarm Planlanması ve Tasarmm. (s. 284-337). Trabzon: Akademi Kitabevi. 
Aytatlı, B. (2013). Erzurum kentinde kişi başına düşmesi gereken aktif açık ve yeşil alan miktarının matematiksel modelle belirlenmesi (Yüksek Lisans Tezi). Atatürk Üniversitesi, Fen Bilimleri Enstitüsü, Erzurum, Türkiye.

Barbarossa, L. (2020). The post pandemic city: Challenges and opportunities for a nonmotorized urban environment: An overview of Italian cases. Sustainability, 12(17), 7172.

Barlas, A. (2012) Komşuluk birimi. Melih Ersoy (Ed.), Kentsel Planlama Ansiklopedik Sözlük 1. Basım (s. 281). İstanbul: Ninova Yayıncılık.

Chae, J. H. ve Kim, W. J. (2020). The evaluation of physical environmental factors in urban parks for healthy city-focus on Seoul. Journal of the Korean Institute of Landscape Architecture, 48(4), 29-40.

Chen, P., Mao, L., Nassis, G. P., Harmer, P., Ainsworth, B. E. ve Li, F. (2020). Coronavirus disease (COVID-19): The need to maintain regular physical activity while taking precautions. J Sport Health Sci, 9, 103-4.

Ciddi, P. K. ve Yazgan, E. (2020). COVID-19 Salgınında sosyal izolasyon sırasında fiziksel aktivite durumunun yaşam kalitesi üzerine etkisi. İstanbul Ticaret Üniversitesi Sosyal Bilimler Dergisi, 19(37), 262-279.

Coppola, D. (2007). Introduction to international disaster management. Oxford: Elsevier.

Çetiner, A. (1972). Şehircilik çalışmalarında donatım ilkeleri. İstanbul: İTÜ.

Deponte, D., Fossa, G. ve Gorrini, A. (2020). Shaping space for ever-changing mobility. COVID-19 lesson learned from Milan and its region. TEMA Journal of Land Use, Mobility and Environment. Special Issue COVID-19 vs City-20, 133-149.

DSÖ (2014). Sağlıklı Kentler Hareketi. Erişim tarihi: 07.12.2020, http://www.skb.gov.tr/wp-content/uploads/2014/05/Sağlıkl1-Kentler-HareketiMay1s-2014.pdf

Eminağaoğlu, Z. ve Yavuz, A. (2010). Kentsel yeşil alanların planlanması ve tasarımını etkileyen faktörler: Artvin ili örneği. III. Ulusal Karadeniz Ormancılık Kongresi, Cilt: IV S: 1536-1547.

Ersoy, M. (2009). Kentsel planlamada arazi kullanım standartları. Ankara: TMMOB Şehir Plancıları Odası Yayınları.

Gedikli, R. (2002). Kentlerde kişi başına düşmesi gereken açık yeşil alan büyüklüğünün değerlendirilmesinde kullanılabilecek matematik model önerisi. Planlama, 4(1), 62-76.

Gehl, J. (1987) Life between buildings. New York: Van Nostrand Reinhold.

Hobday, R. A. ve Cason, J. W. (2009). The open-air treatment of pandemic influenza. American Journal of Public Health, 99(S2), 236-S242.

İnal Çekiç, T. (2020). Salgınla mücadelenin kentsel tezahürü. https://mimdap.org/2020/04/salginla-mucadelenin-kentsel-tezahuru-doc-dr-tuba-inal-cekic/, Erişim tarihi: 02.10.2020.

Joassart-Marcelli, P., Wolch, J. ve Salim, Z. (2011). Building the healthy city: The role of nonprofits in creating active urban parks. Urban Geography, 32(5), 682-711. 
Kaplan, S. (1995). The restorative benefits of nature: Toward an integrative framework. Journal of Environmental Psychology, 15(3), 169-182.

Kıygı, G. (2020). Salgının mekânsal hafızası: norm, ölçek, adalet. Spektrum tasarım rehberleri: Pandemide ve post-pandemide toplum ve mekân: Görüşler, öngörüler, öneriler 2. 47-51.

Kuo, F. E. ve Sullivan, W. C. (2001). Aggression and violence in the inner city: effects of environment via mental fatigue. Environment and Behavior 33, 543-571.

Küçükali, H., Küçükali, İ. ve Taşdemir, M., (2016). Sağlığın yeşil belirleyicileri: Parklar. Sağllk Düşüncesi ve Tıp Kültürü Dergisi, 38, 40-45.

Lai, S., Leone, F. ve Zoppi, C. (2020). COVID-19 and spatial planning. A few issues concerning public policy. TEMA Journal of Land Use, Mobility and Environment. Special Issue I COVID-19 vs City-20, 231-246.

Manlun, Y. (2003). Suitability analysis of urban green space system based on GIS (Master Tezi). International Institute for Geo-Information Science and Earth Observation Enschede, Netherlands) s. 90.

Maxwell, P. (2020). Post-pandemic urbanism: why embracing street life is central to the future of the city. Frame, https://frameweb.com/article/post-pandemic-urbanism-why-embracing-street-life-is-central-to-the-future-of-the-city?fbclid=IwAR2qxqFBJ4SEl25sR0k1Hrj7XMko303C5uCo8g58niRkDewYVUdDL18ka0, Erişim tarihi: 02.10.2020.

Morris, G. P., Beck, S.A., Hanlon, P. ve Robertson, R. (2006). Getting strategic about the environment and health. Public Health, 120, 889-907.

Önder, S. ve Polat, A. T. (2012). Kentsel açık-yeşil alanların kent yaşamındaki yeri ve önemi. Kentsel Peyzaj Alanlarının Oluşumu ve Bakım Esasları Semineri, 19, 73-96.

Peçanha, T., Goessler, K. F., Roschel, H. ve Gualano, B. (2020). Social isolation during the COVID-19 pandemic can increase physical inactivity and the global burden of cardiovascular disease. American Journal of Physiology-Heart and Circulatory Physio$\log y, 318(6), \mathrm{H} 1441-\mathrm{H} 1446$.

Perry, C. (1974). Neighborhood and community planning. Regional Survey of New York and its Environs, 7, 21-140. New York: Arno Press.

Pinheiro, M. D. ve Luis, N. C. (2020). COVID-19 could leverage a sustainable built environment. Sustainability, 12, 5863.

Pisano, C. (2020). Strategies for post-COVID cities: An insight to Paris En Commun and Milano 2020. Sustainability, 12, 5883; doi:10.3390/su12155883.

Sanisa, G., Lafortezza, R., Bonnes, M. ve Carrus, G. (2006). Comparison of two different approaches for assessing the psychological and social dimensions of green spaces. Urban Forestry \& Urban Greening, 5, 121-129.

Sayan Atanur, G. ve Ersöz, N. D. (2020). Kavramsal gelişim süreçleri ve tasarım bileşenleri bağlaminda kent parkları. Ağaç ve Orman, 1(1), 66-71.

Şahin, Ş. ve Barış, M. (1998). Kentsel doku içerisinde açık ve yeşil alan standartlarını belirleyen etmenler. Peyzaj Mimarlığı Dergisi, 6(10), 84 . 
Tuğaç, Ç. (2020). Kentsel sürdürülebilirlik ve kentsel dirençlilik perspektifinden tarihteki pandemiler ve COVID-19 pandemisi. Sosyal Bilimler Enstitüsü Dergisi, Salgın Hastalıklar Özel Sayısı, 259-292.

Ulrich, R. S. (1984). View through a window may influence recovery from surgery. Science, 224, 420-421.

UN Habitat (2020). COVID-19 response report. https://unhabitat.org/un-habitat-covid-19-response-plan, Erişim tarihi: 19.12.2020.

UNDP (2020). BM Kalkınma programı raporu. https://www.tr.undp.org/, Erişim tarihi: 19.12.2020.

Uslu, A. (2007). Kent ekolojisi. Sabri Gökmen (Ed.) Genel Ekoloji. (s. 353-401). Ankara: Nobel Yayınları.

Ward Thompson, C. (2011). Linking landscape and health: The recurring theme. Landscape and Urban Planning 99, 187-195.

World Cities Culture Forum. (n.d.) Metropol kentlerde kamusal yeşil alanların yerleşim içindeki oranı. http://www.worldcitiescultureforum.com/data/of-public-greenspace-parks-and-gardens. Erişim tarihi: 04.12.2020.

Yıldızcı, A. C. (1982). Kentsel yeşil alan planlaması ve İstanbul örneği (Doçentlik Tezi). İTÜ Mimarlık Fakültesi, İstanbul, Türkiye, s. 201.

Yücesu, Ö., Korkut, A. ve Kiper, T. (2017). Kırklareli kent merkezinin açık ve yeşil alanların analizi ve bir sistem önerisi. Artium, 5 (2), 22-37. 